\title{
DETAILED INFORMATION ON FAVIPIRAVIR: DRUG FOR TREATMENT OF SARS-COV-2
}

\author{
MONAJI SANJANA REDDY
}

Department of Samskruti College of Pharmacy, Jawaharlal Nehru Technological University, Hyderabad, Telangana, India. Email: sanjanareddy812@gmail.com

Received: 25 September 2020, Revised and Accepted: 2 November 2020

\section{ABSTRACT}

Severe acute respiratory syndrome corona virus-2 (SARS-CoV-2) is another name given to pandemic disease COVID-19 that is caused by a newly discovered coronavirus. People infected with coronavirus will experience mild-to-moderate respiratory illness, and it can be seen in a serious stage when comorbidities include along with it. This is now creating a huge pandemic situation all over the world with a huge rate of sufferers, that is, around 9.06 million around the world and about $440 \mathrm{k}$ in India till today according to the World Health Organization. This is a serious condition that should be solved with vaccine only as coronavirus is undergoing mutation it makes difficult to invent a vaccine for it. So far, about 200 genetic mutations have been discovered across the world also in these 198 mutations appeared independently more than once. Due to this pandemic situation, there are so many clinical trials going on in discovering vaccines. Recently, after many trails conducting favipiravir are found to be the most successful in treating any stage of SARS-CoV-2. This article focuses completely on this area, along with its mechanism, side effects, uses, and contraindications.

Keywords: SARS-CoV-2, Favipiravir, Future hopes.

(C) 2020 The Authors. Published by Innovare Academic Sciences Pvt Ltd. This is an open access article under the CC BY license (http://creativecommons. org/licenses/by/4. 0/) DOI: http://dx.doi.org/10.22159/ijms.2020.v8i6.39580

\section{INTRODUCTION}

Severe acute respiratory syndrome corona virus-2 (SARS-CoV-2) is caused by a coronavirus. The structure consists of spikes which are a type of protein that is most essential in causing infection to human cells. Furthermore, spikes now are undergoing tremendous changes in a structure known as mutations that change the entire function and properties of the virus and lead to the production of new strain about 14 strains due to mutations in spikes. Beta-coronavirus has three major classes that made zoonosis diseases that include SARS-CoV-2 that occurred in 2002, infected 8000 people, and killed 800 next again after 10 years in 2012 MERS-CoV caused a highly lethal effect about 35\% mortality rate now another class SARS-CoV-2 emerged with heavy loss to human health all over the world and also caused huge loss economically [1]. The novel coronavirus is showing a high rate of mutations; still, there are any researches going on to discover more strains. Due to the pandemic and the situations, the World Health Organization has declared the situation as Public Health Emergency of International Concern [2]

Commonly, all viruses mutate, but speed rate is important in discovering vaccines. Most virus mutations do not change viral protein referred to as silent mutations, while other mutations change the amino acid sequence of viral protein. Even change in sequence does not affect functionally, so these are called inert also some mutations make viruses functionally different making a lineage of a virus [3] Fig. 1 [4]

\section{INFLUENCE OF STRAINS IN VACCINE}

When different strains are evolving, it becomes difficult to invent vaccines as the vaccine provides long-term protection. Normally dose, DNA, and MVA-vaccines encode $S$ glycoprotein neutralizes antibodies also $\mathrm{N}$ protein (induce long-lived memory $\mathrm{T}$ cells) in the case of MERS and SARS. So now, this aspect became a potentially viable alternative long term T-cell immunity against in coronavirus [5].

The strain that is inert will preserve the features that will provide immunity against a whole group of variants which make it easier to study and make a perfect unique target in discovering vaccines against it [6]. As there are more mutations in SARS-CoV-2, an RNA vaccine can be more powerful than involves supplementing a similar section of the genome in the form of RNA into the host body [7].
It became a challenge for scientists all over the world to discover vaccines with no side effects after performing many experiments in different phases and by a comparative study between many drugs they have discovered favipiravir is the most effective drug in treating SARS- CoV-2 [8]. Other drugs work in treating the condition of SARS-CoV-2 such as dexamethasone, lopinavir/ritonavir, ivermectin, and remdesivir [9].

\section{PHASES IN DEVELOPMENT OF VACCINE}

When they find a new vaccine towards any disease, they need to undergo the following process before getting that vaccine into the market:

- Pre-clinical tests: This includes the primary stage first done in vitro (test tube or cell culture) and also in vivo (animals). This process helps testing preliminary efficacy, toxicity, pharmacokinetics, and safety information of vaccines. When this stage passes, then they can try for the next step on human [10].

- Phase - 1: In this phase, they conduct rails in 20-80 humans for several months watching regularly. This phase has a significance in tracing out the highest dose, side effects, and the best route of administration [11].

- Phase - 2: Here, experiments will be done on 25-100 people that they categorize them into different groups and compare the studies between them and intervein the results.

- Phase - 3: In this site, the study size is increased to 3000 participants and this is the last phase of clinical trials and when this passes that they give the approval to release the drug into the market [12].

- Approval: After phase-3 trials, the candidate who performs the experiments applies for approval of his vaccine to release it into the market. However, when there occurs a pandemic situation that vaccines can be approved under emergency authorization [13].

\section{FAVIPIRAVIR IN SARS-COV-2}

The Drug Controller General of India has approved favipiravir as emergency medical use on June 19, in India. Favipiravir is the first oral approved medicine in India for treating SARS-CoV-2 launched by Glenmark Pharmaceuticals with the name FabiFlu for conducting Phase 3 clinical trials in patients with mild-to-moderate symptoms [8]. Hence, it is important to know about side effects mechanism and details about favipiravir 


\section{STRUCTURE}

Favipiravir is a new RNA polymerase inhibitor that is previously used in treating influenza-A and B. It also works as an antiviral ebolavirus, sand virus, bunia virus, and rabies virus [14]. The chemical structure is known as T-705; 6-fluoro-3-hydroxy-2-pyrazine carboxamide (pyrazine carboxamide derivative). This undergoes intracellular phosphoribosylation to form an active substance that is favipiravir ribofuranosyl-5'-triphosphate (favipiravir-RTP) [14], as shown in Fig. 2 [15].

\section{MECHANISM}

The active form, that is, favipiravir RTP interacts with RNA dependent RNA polymerase to inhibit replication of viral genome in host cells. Furthermore, from another hypothesis, it is thought to be that the active form can be incorporated into the nascent RNA strand and prevents its elongation and viral proliferation an transcription [16].

\section{DOSAGE}

Dosage includes $200 \mathrm{mg}^{*} 9$ tabs on $1^{\text {st }}$ day followed by $200 \mathrm{mg}^{*} 4$ tablets for next 14 days [17].

From the preliminary report by Japan, it is clear that when they performed an observational study they found that about $73.8 \%$ of mild, $66.6 \%$ of moderate, and $40.1 \%$ of the severe condition of SARS-CoV-2 had improved their condition after 7 days start of favipiravir; improved outcome after 14 days for mild cases is $87.8 \%$, for moderate cases is $84.5 \%$, for severe cases is $60.3 \%$ also more than $50 \%$ of patients with a mild infection, $42.7 \%$ with moderate, and $14.7 \%$ with severe infection had discharged alive from hospital [18].

\section{PHARMACOKINETICS}

According to studies from japan on protein binding capacity in human serum albumin is about $65 \%$ and to $\alpha_{1}$-acid glycoprotein is $6.5 \%$ it is found that the maximum plasma concentration of favipiravir is $2 \mathrm{~h}$ from oral administration while the half-life is $2-5.5 \mathrm{~h}[19]$.

\section{Absorption}

The bioavailability is about $97.6 \%$ and the Cmax is 51.5 $\mu \mathrm{g} / \mathrm{mL}$. Favipiravir has many interactions with 200 types of food items that decrease Cmax so to compensate tis the dose needs to be increased [16]. Drug-drug interactions can lead to serious conditions, especially in patients with comorbidities and complications such as hypertension, diabetes, and cardiovascular disease [19].

\section{Distribution}

As favipiravir is a prodrug and its activation occurs in the liver; also, the volume of distribution will be different between prodrug (favipiravir) and active metabolite (favipiravir-RTP). There are still ongoing experiments at the clinical trial stage [20]. However, for favipiravir, the volume of distribution is $15-20 \mathrm{~mL}$ [21]

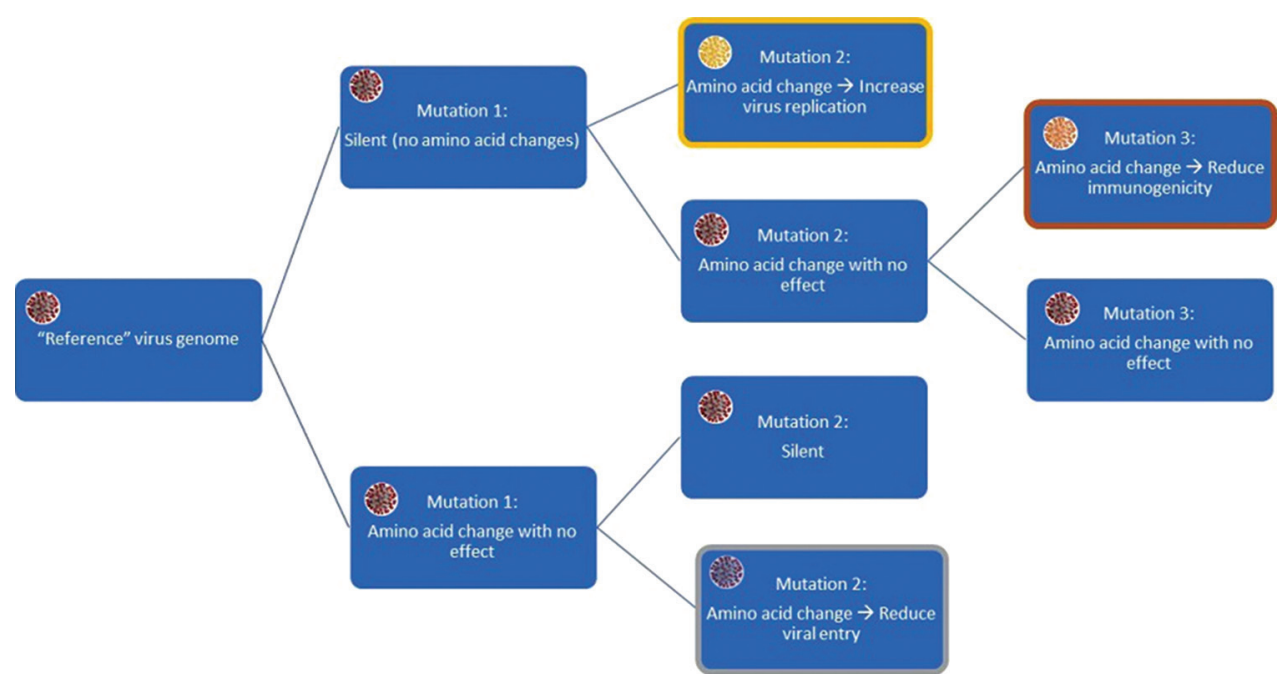

Fig. 1:

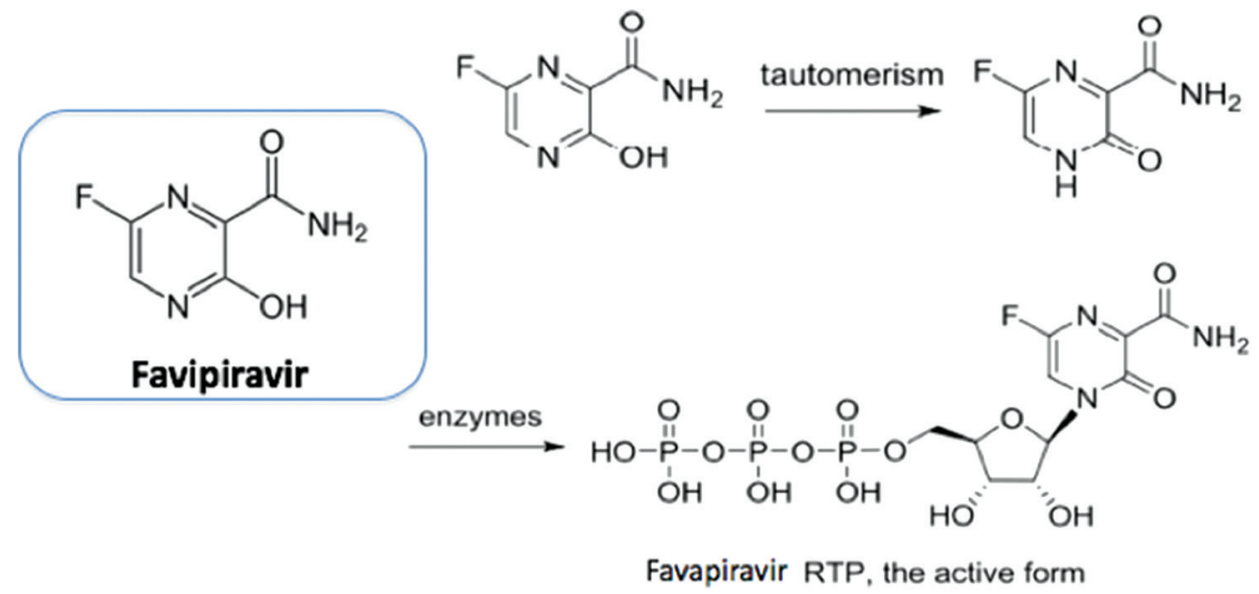

Fig. 2: Intracellular phosphoribosylation [15] 


\section{Metabolism}

Normally, all the antivirals undergo hydroxylation primarily by aldehyde oxidase and also by xanthine (minimum effect) [22]. From studies, it is found that human liver microsomes are sites for hydroxylation that forms favipiravir hydroxylate at a range of 3.98-47.6 pmol/mg protein/ min. The range may vary with the average of aldehyde oxidase activity by 12 times to maximum [23]. Along with hydroxylating, glucuronate conjugate is also observed in human plasma [24].

\section{Excretion}

It is excreted through urine in hydroxylate form also a little amount of unchanged drug in the ratio of 53.1\%:0.8\%, respectively [23]

\section{Toxicity}

There is no information about toxicity levels in humans, while in another family, there is information as follows: Lethal dose for oral and intravenous in mice is estimated more than $2000 \mathrm{mg} / \mathrm{kg}$, the lethal dose for oral administration in rats is $>2000 \mathrm{mg} / \mathrm{kg}$, and lethal dose for dog and monkeys is $>1000 \mathrm{mg} / \mathrm{kg}$ [21].

\section{Symptoms of overdose}

Reduced body weight, vomiting, and decreased locomotor activity. While when it comes to dogs, rats, and monkeys with oral administration that include decreased red blood cells; increased liver function parameters such as AST, ALP, ALT, and bilirubin; increased vacuolation in hepatocytes; also, testis toxicity is also observed [22].

\section{Pregnancy and lactation}

Favipiravir is teratogenic, so it is contraindicated in pregnancy and also in breastfeeding women, it is contraindicated as it is excreted in breast milk [25].

\section{Dosage adjustments}

\section{Hepatic impairment}

When favipiravir toxicity occurs, it still worsens the situation in liver functioning. Hence, the doe should be maintained.

\section{Renal impairment}

As it is excreted through urine in different forms, it should be monitored in patients with renal failure. However, the dosage is still under clinical trials [23].

\section{Use in pediatrics}

The efficacy and safety of children are not found yet [23].

\section{Adverse drug reactions}

Increased blood uric acid, hypersensitivity reactions, and a little effect on the respiratory system, blurred eye vision, and vertigo.

Monitoring parameters in patients with:

Shock, anaphylaxis, pneumonia, hepatitis, jaundice, acute kidney disease, decreased WBC, neurological and psychiatric symptoms, colitis hemorrhage [23].

List of contraindicated drugs:

There is a big list of drugs that interact with favipiravr and has an effect on pharmacokinetics and pharmacodynamics. The list can be checked here (drug bank) [21].

\section{DISCOVERY}

Favipiravir has been used as an anti-influenza virus that ranged from 0.013 to $0.48 \mu \mathrm{g} / \mathrm{ml}$ for influenza A virus, from 0.039 to $0.089 \mu \mathrm{g} / \mathrm{ml}$ for influenza B virus, and 0.030 to $0.057 \mu \mathrm{g} / \mathrm{ml}$ for influenza $\mathrm{C}$ virus. The mammalian cell lines like Madin-Darby Canine Kidney Cells (MDCK cells), Vero cells there is no toxicity shown up to $1000 \quad \mu \mathrm{g} / \mathrm{ml}$ MDCK cells are inoculated with seasonal influenza viruses and seen for the lethal effects.

The cell data are shown in Table 1

The clinical research method includes the assay with XXT. XXT is first converted to aqueous formazan by an enzyme in cells, in which we are looking for testing. The compounds are then diluted to the concentration like the volume of $100 \mu \mathrm{l}$ with test medium in 96 wellcultured plates that contain a concentration of $2 \times 10^{3}$ cells $/ 100 \mu \mathrm{L}$. The test plate is incubated for 3 days at $37^{\circ} \mathrm{C}$ in $100 \%$ humidity and $5 \%$ $\mathrm{CO}_{2}$. After 3 days, $50 \mu \mathrm{l}$ of XXT reagent that contains $1 \mathrm{mg} / \mathrm{ml}$ in FCS free EMEM containing $5 \mathrm{Mm}$ phenazine methosulfate is added, and the reaction product is assayed [26]

\section{RECENT UPDATES ON FAVIPIRAVIR IN SARS-COV-2 TREATMENT}

There are many clinical trials going on in different countries all over the world and different stages. The list is as follows:

- From clinical study to evaluate, the performance and safety of favipiravir in COVID-19 that has been conducting from March 2020 It is randomized, double-blind and placebo-controlled (1:1), the screening process is done from 10 days after the onset of COVID-19. Here, there is given favipiravir with $1800 \mathrm{mg}$ BID on $1^{\text {st }}$ day and 600 mg TID for the next 14 days and the other groups were given with placebo with the same dose. These groups are made a comparative study to evaluate the efficacy of favipiravir in 100 subjects. In this, I subject has any renal impairment that the dose has decreased to 600 mg BID even then if adverse reactions continue then the subject is discontinued from treatment. Still, the trail is in Phase 3 in Italy, for the outcome of clinical recovery for the time frame of 90 days [27].

- From a multi-center, randomized, double-blind, and placebocontrolled, Phase 3 study evaluating favipiravir for treatment of COVID-19 started from May 2020 for the outcome of recovery with a time frame of 28 days with favipiravir or placebo administration to normalize the conditions such as respiratory rate, $\mathrm{SPO}_{2}$, and relief from cough. With the administration of favipiravir combined with supportive care with a dose of $1800 \mathrm{mg}^{*} 2$ for day- 1 and with $600 \mathrm{mg}^{*} 3$ for the next 14 days and other with placebo according to current national/local guidelines. This is going on in China, Germany, and Romania [28].

- Another study of the use of favipiravir in hospitalized subjects with COVID-19 conducting in the United States starting from April 2020 to determine the effect of favipiravir plus standard of care (SOC) with that of the only SOC on viral clearance of COVID-19 as measured by nasopharyngeal and oropharyngeal sampling for the time frame of 29 days. The interventional study is in Phase 2 by administering 1800

Table 1:

\begin{tabular}{|c|c|c|c|}
\hline Cell lines & $\begin{array}{l}\text { Assay } \\
\text { type }\end{array}$ & $\begin{array}{l}\text { Incubation } \\
\text { time }\end{array}$ & Activity description \\
\hline $\begin{array}{l}\text { MDCK } \\
\text { cells }\end{array}$ & $\begin{array}{l}\text { Function } \\
\text { assay }\end{array}$ & & $\begin{array}{l}\text { Inhibition of viral replication } \\
\text { of influenza A virus (A/Hong } \\
\text { Kong/213/03 [H5N1]) and } \\
\text { influenza A virus (A/Ann } \\
\text { Arbor/6/60 [H2N2]) hybrid } \\
\text { virus in MDCK cells by neutral } \\
\text { red uptake assay }\end{array}$ \\
\hline Vero cells & $\begin{array}{l}\text { Function } \\
\text { assay }\end{array}$ & 7-8 days & $\begin{array}{l}\text { Antiviral activity against } \\
\text { Junin virus Candid- } 1 \text { in Vero } \\
\text { cells assessed as inhibition of } \\
\text { virus-induced visual cytopathic } \\
\text { effect after } 7-8 \text { days }\end{array}$ \\
\hline $\begin{array}{l}\text { MDCK } \\
\text { cells }\end{array}$ & $\begin{array}{l}\text { Function } \\
\text { assay }\end{array}$ & & $\begin{array}{l}\text { Inhibition of influenza } \\
\text { A virus (A/duck/ } \\
\text { Minnesota/1525/1981 [H5N1]) } \\
\text { replication in MDCK cells by } \\
\text { neutral red uptake assay }\end{array}$ \\
\hline
\end{tabular}


mg BID favipiravir plus SOC or SOC alone on day-1 then $1000 \mathrm{mg}$ BID favipiravir plus SOC or SOC alone for the next 13 days, but if the subject is suffering from any liver impairment dose was decreased to $800 \mathrm{mg}$ BID. The study is done for 14 days treatment follow-up for the next 46 days in about 50 patients in three different sites of the US for the outcome [29].

- The completed clinical trial on the study of safety and efficacy of favipiravir in management of COVID-19 started in April and completed on June 12020 in about 100 subjects for the outcome of viral clearance at 14 days' time frame by conducting PCR analysis test at $48-72 \mathrm{~h}$ apart and also clinical improvement at 14 days' time frame by administering favipiravir at $3200 \mathrm{mg}$ (1600 mg 12 hourly) on day-1 then $1200 \mathrm{mg}$ ( $600 \mathrm{mg} 12$ hourly daily) for 10 days and in another group for comparison by administering oseltamivir $75 \mathrm{mg}$ 12 hourly for $5-10$ days and hydroxychloroquine $400 \mathrm{mg} 12$ hourly day 1 followed by $200 \mathrm{mg} 12$ hourly for day 2-day 10 and comparison was done between these groups done in Egypt [30].

- By study on oral favipiravir compared to placebo in subjects with mild COVID-19 going from April 2020 in Phase 2 randomized, doubleblinded, and placebo-controlled study of oral favipiravir comparing with the SOC in subjects with mild or asymptomatic COVID-19 by administering SOC plus favipiravir for 10 days and evaluated for 28 days and in another group SOCplus placebo that is equal to favipiravir for 10 days and evaluated for 28 days for the study done by US [31].

Many clinical trials are going on, but few are listed above others can be seen on the clinicaltrails.gov website.

Even there are some conditions, where favipiravir is used in treating the condition of pneumonia progression and cytokine increase and also to improve the condition of respiratory function and produce immediate relief from critical or severe conditions even [32].

Future health care, a pharma company has announced to launch favipiravir drug under the brand name XARAVIR to treat mild and moderate COVID-19 cases [33].

\section{COMBINATION THERAPY}

\section{With methylprednisolone}

When favipiravir, along with methylprednisolone, was administered in patients with a severe condition of COVID-19 and they are on the ventilator as they have SPO $2<93 \%$ which have been recovered well and even they do not require ventilator further but the administration should be started in early-stage only to achieve favorable outcomes [34].

\section{With umifenovir}

Glenmark has approved that an antiviral combination can effectively be used in high viral loads in the early stage of the disease such as umifenovir that has that the combined effect has a comprehensive antiviral cover on the pre-entry and post-entry life cycle of SARS-CoV-2. The combination has shown its effectiveness in clinical trials, and further studies are carrying on [35].

\section{CONCLUSION}

For SARS-CoV-2, there are still many drugs that are being discovered that are in several stages of trails, but favipiravir is the first oral drug that is launched by Glenmark. There are still trails going on for combination therapy with favipiravir, hoping for good results to discover them. This article gives detailed information about favipiravir.

\section{ACKNOWLEDGMENT}

I thank anonymous referees for their useful suggestions.

\section{REFERENCES}

1. Korber B, Fischer WM, Yoon H, Theiler J, Abfalterer W, Gnanakaran S, et al. Spike mutation pipeline reveals the emergence of a more transmissible form of SARS-CoV-2. BioRxiv 2020;
2. Kumudhaveni B, Kathirvel S, Deepak Muthu S, Jeradsuresh A, Radha R. Potential drug candidates for treatmentof covid-19. Int J Pharm Sci Res 2017; Available from:https://www.ijpsr.com/bft-article/potential-drug-candidates-for-tre atment-of-covid-19 accessed on 2020 Sep 18]

3. Variants, Lineages, and Strains of Coronavirus-the Startup-medium Available from: https://www.medium.com/swlh/variants-lineages-andstrains-of-coronavirus-7a71a0e699d7. [Last accessed on 2020 Jun 23].

4. Available from: https://www.miro.medium.com max/1400/1*H0nTPEvFofne4A216InfgA.jpeg. [Last accessed on 2020 Jun 23].

5. Padron-Regalado E. Vaccines for SARS-CoV-2: Lessons from other coronavirus strains. Infect Dis Ther 2020;9:255-74.

6. COVID-19 Will Mutate-what That Means for a Vaccine. Available from: https://www.healthline.com/health-news/what-to-know-aboutmutation-and-covid-19\#What-this-means-for-a-vaccine. [Last accessed on 2020 Jun 23].

7. What Is a Coronavirus Vaccine? Available from: https://www. sciencealert.com/coronavirus-vaccine. [Last accessed on 2020 Jun 23].

8. Favipiravir for Coronavirus Treatment: Check how Glenmark's Covid-19 Medicine FabiFlu Works-the Financial Express. Available from: https://www.financialexpress.com/lifestyle/health/favipiravirfor-coronavirus-treatment-check-how-glenmars-covid-19-medicinefabiflu-works/1999512. [Last accessed on 2020 Jun 25].

9. Treatment of Coronavirus Disease 2019 (COVID-19): Investigational Drugs and Other Therapies: Introduction, Investigational Antiviral Agents, Immunomodulators and Other Investigational Therapies. Available from: https://www.emedicine.medscape.com/ article/2500116-overview\#a2. [Last accessed on 2020 Jun 23].

10. The Phases of Preclinical and Clinical Trials. Available from: https:// www.profil.com/knowledge-center/trial-stages. [Last accessed on 2020 Jun 25].

11. Clinical Trial Phases: What Happens in Phase 0, I, II, III, and IV Available from: https:/www.healthline.com/health/clinical-trialphases\#phase-i. [Last accessed 2020 Jun 25].

12. What is a Phase 3 Clinical Trial? Available from: https://www.newsmedical.net/health/What-is-a-Phase-3-Clinical-Trial.aspx. [Last accessed on 2020 Jun 25].

13. Coronavirus, Covid-19 Vaccine India Latest News Update: How Close Are we to a Covid-19 Vaccine, What is the Testing Process? Available form: https:/www.indianexpress.com/article/explained/howclose-are-we-to-coronavirus-covid-19-vaccine-what-is-the-testingprocess-6471283. [Last accessed on 2020 Jun 25].

14. What is Favipiravir? How Does It Work for COVID-19? Huateng Pharma Pharmaceutical Chemical Reagents, PEG Derivatives. Available from: https://www.en.huatengsci.com/article/140.html. [Last accessed on 2020 Jun 25].

15. Available from: https://www.scientificupdate.com/wp-content/ uploads/2020/04/Picture2.png. [Last accessed on 2020 Jun 25].

16. Favipiravir-drugbank. Available from: https://www.drugbank.ca/drugs/ DB12466. [Last accessed on 2020 Jun 27]

17. Glenmark Says FabiFlu Reduces Viral Load by 4 Days, Treats Mild to Moderate COVID-19. Business News-India TV. Available from: https:/www.indiatvnews.com/business/news-fabiflu-tablets-dosagecovid-19-treatment-favipiravir-glenmark-indian-company-getsapproval-628184. [Last accessed on 2020 Jun 27].

18. Favipiravir Observational Study Group. Preliminary Report of the Favipiravir Observational Study in Japan. China: Favipiravir Observational Study Group; 2020

19. Favipiravir: Pharmacokinetics and Concerns About Clinical Trials for $2019 \square \mathrm{nCoV}$ Infection-du--clinical Pharmacology TherapeuticsWiley Online Library. Available from: https://www.ascpt. onlinelibrary.wiley.com/doi/pdf/10.1002/cpt.1844. [Last accessed on 2020 Jun 27].

20. IrieK, Nakagawa A, Fujita H, Tamura R, Eto M, Ikesue H, et al. Pharmacokinetics of favipiravir in critically ill patients with COVID $\square 19$. Clin Transl Sci 2020;13:880-5.

21. Favipiravir DrugBank. Available from: https:/www.drugbank.ca/ drugs/DB12466\#BE0009866. [Last accessed on 2020 Jun 28].

22. Favipiravir C5H4FN3O2. Available from: https://www.pubchem.ncbi. nlm.nih.gov/compound/492405\#section=Metabolism-Metabolites. [Last accessed on 2020 Jun 28].

23. Avigan 英文仿單. Available from: https://www.cdc.gov.tw/File/Get/ ht8jUiB MI-aKnlwstwzvw. [Last accessed on 2020 Jun 28].

24. Reaction: Favipiravir to 1 Product DrugBank. Available from: https:// www.drugbank.ca/reactions/5550. [Last accessed on 2020 Jun 28].

25. Favipiravir-drugs and Lactation Database (LactMed). Available from: 
https://www.ncbi.nlm.nih.gov/books/NBK556878. [Last accessed on 2020 Jun 28]

26. Favipiravir (T-705) $\geq 99 \%$ (HPLC) Selleck DNA/RNA Synthesis Inhibitor. Available from: https://www.selleckchem.com/products/ favipiravir-t-705.html. [Last accessed on 2020 Sep 08].

27. Clinical Study to Evaluate the Performance and Safety of Favipiravir in COVID-19-tabular View. Available from: https://www.clinicaltrials gov/ct2/show/record/NCT04336904?term=favipiravir\&cond=Covid$19 \&$ draw $=2 \&$ rank $=1$. [Last accessed on 2020 Jun 28]

28. A Multi-center, Randomized, Double-blind, Placebo-controlled, Phase 3 Study Evaluating Favipiravir in Treatment of COVID19tabular. Available from: https://www.clinicaltrials.gov/ct2/show/record/ NCT04425460?term=favipiravir\&cond $=$ Covid-19\&draw $=2 . \quad$ [Last accessed on 2020 Jun 28].

29. Study of the Use of Favipiravir in Hospitalized Subjects With COVID-19tabular View. Available from: https://www.clinicaltrials.gov/ct2/show/ record/NCT04358549?term $=$ favipiravir\&cond $=$ Covid19\&draw $=2$. [Last accessed on 2020 Jun 29].

30. Efficacy and Safety of Favipiravir in Management of COVID-19tabular View. Available fom: https://www.clinicaltrials.gov/ct2/show/ record/NCT04349241?term=favipiravir\&cond=Covid19\&draw $=2$.
[Last accessed on 2020 Jun 29].

31. Oral Favipiravir Compared to Placebo in Subjects With Mild COVID-19tabular View. Available from: https://www.clinicaltrials.gov/ct2/show/ record/NCT04346628?term $=$ favipiravir\&cond $=$ Covid19\&draw $=2$. [Last accessed on 2020 Jun 29].

32. Takahashi H, Iwasaki Y, Watanabe T, Ichinose N, Okada Y, Oiwa A, et al. Case studies of SARS-CoV-2 treated with favipiravir among patients in critical or severe condition. Int J Infect Dis 2020;100:283-5.

33. Fusion Health Care Launches Favipiravir for COVID-19 Treatment Available from: https://www.expresspharma.in/covid19-updates/fusionhealth-care-launches-favipiravir-for-covid-19-treatment. [Last accessed on 2020 Sep 08]

34. Murohashi K, Hagiwara E, Kitayama T, Yamaya T, Higa K, Sato Y, et al. Outcome of early-stage combination treatment with favipiravir and methylprednisolone for severe COVID-19 pneumonia: A report of 11 cases. Respir Investig 2020;

35. Glenmark to Study Potential COVID-19 Drug Combination on Favipiravir, Umifenovir in India. Available from: https://www.oneindia. com/india/glenmark-to-study-potential-covid-19-drug-combinationon-favipiravir-umifenovir-in-india-3094526.html. [Last accessed on 2020 Sep 08] 